\title{
Serum bone profile and cathepsin K expression as a prognostic factor in patients with and without breast cancer metastasis
}

\author{
Yaongamphi Vashum ${ }^{1,2}$, () Thiagarajan Krishnamurthi', (i) Mathangi Soma ${ }^{\text {, }}$, Fathima Bushra Sheriff $\mathbf{M}^{1}$, \\ Shila Samuel ${ }^{1}$ \\ 'Department of Biochemistry, VRR Institute of Biomedical Science (Affiliated to University of Madras), Chennai, India \\ ${ }^{2}$ Department of Biochemistry, Armed Forces Medical College, Pune, Maharashtra
}

\begin{abstract}
Objectives: Breast cancer is the most frequently diagnosed cancer and the leading cause of cancer-related death among women worldwide. Breast cancer bone metastasis is associated with skeletal events, including acute fractures, compression of the spinal cord, surgery and radiotherapy to the spine, as well as bone pain and hypercalcemia, resulting in decreased mobility and diminished quality of life. Greater understanding of the bone metastasis pathophysiology will highly likely to lead to the discovery of an effective treatment option. This study aims to test whether the serum bone profile and expression level of cathepsin K (CTSK) in breast carcinoma is associated with metastasis.

Methods: In this study, 116 participants, 58 patients who had been diagnosed with breast cancer ( $n=22$ without metastasis and $n=36$ with metastasis) and 58 healthy controls were included. Serum biochemical profile and immunostaining of CTSK in the breast carcinoma were investigated.

Results: The mean values of calcium, 25-OH Vitamin D, ALP, albumin, phosphorus, magnesium, TSH, cholesterol, PTH and CRP $(\mathrm{mg} / \mathrm{L})$ were $11.5 \pm 2.03,28.12 \pm 10.5,93.3 \pm 7.9,3.9 \pm 0.3,3.7 \pm 1.64,1.8 \pm 0.24,2.5 \pm 1.5,165.1 \pm 28.02,63.4 \pm 18.9$ and $7.7 \pm 4.9$. Individual data revealed that $70 \%$ of patients without metastasis has PTH above normal while $65 \%$ has calcium and $62 \%$ patients has ALP above normal levels, which were further increased in metastasis. Low Mg levels were detected in 13/58 of the patients with breast cancer and 3/58 of the control group.13/58 of the patients with breast cancer showed low total calcium, and 32/58 of the breast cancer group showed high calcium levels.

Conclusion: The present study results suggest that CTSK expressions are associated with a higher tumour stage and distant metastasis, suggesting serum bone profile and level of CTSK expression are significant parameters in the disease diagnosis and monitoring of breast cancer metastasis.

Keywords: Breast cancer, cathepsin K, immunohistochemistry, serum bone marker
\end{abstract}

$B^{\prime}$ reast cancer is the most common malignancy among women and the leading cause of death. The majority of the cases are diagnosed at an advanced stage with a higher incidence of skeletal metastases [1-3]. Metastatic disease to the bone has been a crippling devastating complication of breast cancer, leaving patients bedridden or wheelchair-bound and victims of suffering from intolerable pain. The biological mechanisms leading to bone metastasis have been referred to as "vicious cycle" a complex network between cancer cells and the bone microenvironment [4].

Besides clinical and imaging techniques, biochemical tests play a vital role in the assessment and differential diagnosis of bone metabolic disorder in breast cancer [5]. These biochemical indices are non-invasive, comparatively low-cost and when applied and interpreted correctly, it is a great tool among the diagnostic and therapeutic assessment of metabolic bone

Address for correspondence: Shila Samuel, MD. Department of Biochemistry, VRR Institute of Biomedical Science (Affiliated to University of Madras), Chennai, India

Phone: +91- 9445787424 E-mail: shilasamuel@gmail.com ORCID: 0000-0001-6848-1873

Submitted Date: June 26, 2020 Accepted Date: August 10, 2020 Available Online Date: October 06, 2020

${ }^{\circ}$ Copyright 2020 by International Journal of Medical Biochemistry - Available online at www.internationalbiochemistry.com OPEN ACCESS This work is licensed under a Creative Commons Attribution-NonCommercial 4.0 International License. 
disease. However, the role of serum bone profile as a risk of skeletal metastasis has been under-researched.

CTSK is a papain-like cysteine protease, involved in bone remodeling, produced by cancer cells that metastasize to the bone where it acts in proteolytic pathways that facilitate the invasion of cancer cells and has been widely used as an immunohistochemical marker for osteoclasts in situ detection [6, 7]. CTSK expression has shown to be increased considerably in primary cases of breast cancer with skeletal metastasis [8]. CTSK expression has also been very well associated with tumour proliferation and progression in colorectal, gastric, prostate, oral squamous and glioblastoma cancers [9-12].

There are several studies concerning the diagnostic value of breast cancer bone turnover markers for bone metastases. However, their uses in the diagnosis are not yet fully validated. Much of the studies were derived predominantly from retrospective analyses. Bone markers for the diagnosis and management of bone metastasis are significantly hindered by biological and analytical variability multiple confounding factors (tumour burden, malnutrition, chemotherapy, radiotherapy, immobility) causing variations in their concentrations [13]. Therefore, this study aimed to assess the serum bone profile in patients with breast cancer in comparison with healthy controls and to determine the relationship between CTSK expression, including mild, moderate and high levels and breast cancer metastasis. Further, we compared the CTSK expression in different types of breast cancer based on histopathology and receptor status to evaluate the association with specific subtypes.

\section{Materials and Methods}

The present study included 58 clinically established breast cancer female patients ranging in age from 34 to 74 years with the mean age of $58.6 \pm 12.4$. Ethical approvals for this study were taken from Saveetha Medical College \& Hospital Chennai and Gleneagles Global Health City Hospital Chennai, India. Patients were prospectively identified and registered. All samples were taken after institutional ethical committee permissions and personal consent of the patients or guardians. All patients had histologically confirmed breast cancer. The histopathological diagnosis of breast cancer, grade, stage of the tumour, and hormone receptor status (estrogen receptor ER, progesterone receptor PR and Her2neu) were recorded from the pathology reports of breast cancer patients.

The blood samples were collected from the patients in heparinized tubes. The collected samples were analyzed for age, weight, and body mass index (BMI) and biochemical profile of blood. The parameters like total cholesterol, triglycerides, HDL-C, LDL-C, C-reactive protein (CRP), calcium, 25-OH Vitamin D and tumour markers CEA, CA 15-3, Vitamin D, parathyroid hormone (PTH), serum alkaline phosphatase (ALP), albumin, phosphorus (Phosphomolybdate), magnesium were included in this study.

\section{Inclusion criteria}

The confirmed cases of breast cancer by mammography and histological examination were chosen for this study. Controls were individuals without clinical cases who were seen at the same hospital for an annual physical examination.

\section{Exclusion criteria}

Patients suffering from any other cancer as well as diabetes mellitus and dyslipidemia, osteoporosis with drug treatment were excluded from this study.

\section{Immunohistochemistry studies (IHC)}

Invasive ductal carcinoma was diagnosed with low to the moderate distinction among donors. The tissue microarray (TMA) slides were made from tissue donors and contained at least two cores per patient ( $1 \mathrm{~mm}$ in diameter). Samples were examined for classification by the vendor's pathologist regarding histopathology, class, the involvement of the lymph node, and tumour grade. Samples were classified based on tumour-node-metastasis (TNM) classification of: the size of the primary tumour $(\mathrm{T})$, degree of regional lymph node involvement (N), and the existence of distal metastasis (M). Endogenous peroxidase was quenched by incubation of tissues in $0.3 \%$ hydrogen peroxide in PBS for $10 \mathrm{~min}$. Nonspecific binding was blocked for $1 \mathrm{~h}$ at room temperature with serum $(5 \%$ goat sera) in phosphate-buffered saline. Endogenous biotin was blocked with an avidin/biotin blocking kit. An affinity pure goat antibody against human CTSK was applied at 40 $\mathrm{ng} / \mathrm{ml}$, and the part were incubated in a humidified chamber at $4^{\circ} \mathrm{C}$ overnight. Sections in Harris hematoxylin and blue in ammonia water were counterstained before mounting. Giant cell tumour tissues were used for CTSK staining as positive regulation.

The criteria used for assessing the immunostaining of the breast tumour were as follows. The degree of staining was taken as a sum of the strength of staining and the percentage of stained cells: negative/mildly stain $(-)=0-1$; moderately positive $(2+)=2-3$; strongly positive $(3+)=4$. Almost all strongly positive had a widely stained area $>4$.

\section{Statistical analysis}

Data were presented as mean \pm standard deviation (SD). The normality of the data was checked using the Shapiro-wilk test. In case of data not following a normal distribution, the median was presented. For data following normal distribution, differences between groups were assessed by one way ANOVA. Pearson correlation was performed to evaluate correlation analysis between the tumour markers with a bone mineral profile in the breast cancer group. The chi-square test was performed to evaluate the relationship between CTSK expression and clinicopathological features and metastasis. All statistical analyses were conducted with graph pad prism 6.0 software package for windows. 


\section{Results}

\section{Biochemical profile analysis}

The average age of the breast cancer group $(n=58)$ and of the control group $(n=58)$ was $59.1 \pm 8.03$ median 57.5 and $58.6 \pm 12.4$ median 56.5. Clinical, demographic, and biochemical characteristics of the study groups are are presented in Table 1. According to baseline parameters, there was no significant difference in the Body Mass Index (BMI) $(p<0.0381)$, fasting plasma glucose $(p<0.0844)$, age $(p<0.8409)$, total cholesterol $(p<0.12)$.

\section{Bone profile analysis}

Individual data revealed that $70 \%$ of patients without metastasis had PTH above normal while $65 \%$ had calcium and $62 \%$ of the patients had ALP above normal levels which further increased in metastasis.

The patients with breast cancer and control subjects showed significant differences in calcium, PTH and C-reactive protein level, demonstrating an appropriate match in the risk factors for breast cancer. 25-OH Vitamin D deficiency was considered at serum level less than $20 \mathrm{ng} / \mathrm{ml}$, suboptimal $25-\mathrm{OH}$ Vitamin D levels were considered between 21 and $39 \mathrm{ng} / \mathrm{ml}$ and optimal levels were more than $40 \mathrm{ng} / \mathrm{ml}$ (27). 25-OH Vitamin D deficiency was seen in $36.2 \%(21 / 58)$ patients with breast cancer, while $45.4 \%(26 / 58)$ of the control group was deficient. Phosphorus was deficient in 5/58 and was high in $1 / 58$ of the breast cancer group and $6 / 58$ of the normal control group.

Deficient Mg levels were detected in 13/56 of the patients with breast cancer and 3/22 of the control group. Regarding calcium level, $13 / 58$ of the patients with breast cancer showed low total calcium and 32/58 of the breast cancer group showed high calcium levels (Table 1). Correlation analysis between the breast cancer tumour markers and bone profile in the breast cancer group are presented in Table 2 . Serum calcium was significantly high in the patients with breast cancer reflecting the tight control of serum calcium by calcium-regulating hormones such as PTH and $25-\mathrm{OH}$ Vitamin D. Concerning serum PTH, the concentration of PTH in
Table 1. Baseline characteristics of this study

\begin{tabular}{llll}
\hline Parameter & $\begin{array}{l}\text { Control } \\
\text { (n=58) }\end{array}$ & $\begin{array}{l}\text { Breast cancer } \\
\text { (n=58) }\end{array}$ & p \\
\hline Age (years) & $59.1 \pm 8.03$ & $58.6 \pm 12.4$ & 0.8409 \\
Height (cm) & $158 \pm 5.7$ & $161.07 \pm 7.63$ & 0.2054 \\
Weight (kg) & $68.2 \pm 9.9$ & $66.3 \pm 10.33$ & 0.0844 \\
BMI (kg/m²) & $31.4 \pm 4.6$ & $27.5 \pm 4.3$ & 0.0381 \\
CA 15-3 (U/ml) & $7.9 \pm 2.3$ & $105.3 \pm 41.6$ & $<0.0001$ \\
CEA(U/ml) & $0.99 \pm 0.2$ & $56.3 \pm 21.6$ & $<0.0001$ \\
Calcium (mg/dL) & $8.5 \pm 0.5$ & $11.15 \pm 2.03$ & $<0.0001$ \\
25-OH VitD (ng/ml) & $25.39 \pm 9.4$ & $27.8 \pm 4.8$ & 0.557 \\
ALP (U/L) & $76.5 \pm 21.3$ & $93.3 \pm 7.9$ & $<0.0001$ \\
Albumin (g/dL) & $4.2 \pm 0.2$ & $3.9 \pm 0.3$ & $<0.05$ \\
Phosphorous (mg/dL) & $4.3 \pm 1.62$ & $3.7 \pm 1.64$ & $<0.0001$ \\
Magnesium (mg/dL) & $2.3 \pm 0.23$ & $1.8 \pm 0.24$ & $<0.05$ \\
TSH (IU/ml) & $2.07 \pm 1.3$ & $2.5 \pm 1.5$ & 0.478 \\
Cholesterol (mg/dL) & $175.1 \pm 29.0$ & $165.1 \pm 28.02$ & 0.12 \\
PTH (pg/ml) & $37.62 \pm 22.1$ & $63.4 \pm 18.9$ & $<0.0001$ \\
HDL (mg/dL) & $40.09 \pm 6.5$ & $53.9 \pm 7.08$ & 0.0002 \\
LDL (mg/dL) & $91.5 \pm 31$ & $83.2 \pm 27.5$ & 0.4954 \\
VLDL (mg/dL) & $35.5 \pm 5.01$ & $28 \pm 3.2$ & $<0.0001$ \\
TGL (mg/dL) & $177.5 \pm 27.3$ & $180.4 \pm 16.4$ & 0.034 \\
Chol/HDL ratio & $4.1 \pm 1.01$ & $3.09 \pm 0.5$ & 0.0061 \\
CRP (mg/L) & $2.7 \pm 1.01$ & $7.7 \pm 4.9$ & $<0.0001$ \\
\hline
\end{tabular}

serum was significantly higher in patients with breast cancer than in control subjects (Table 2). The results showed that patients with breast cancer and control subjects were both 25-OH Vitamin D deficient. In this study, the protein albumin level significantly reduced in patients with breast cancer as compared with normal $(p<0.05)$.

Bone profile with some prognostic factors profile between pre and post-menopausal women in breast cancer metastasis and non-metastasis group

Comparing the studied bone profile with some prognostic factors in the breast cancer group is shown in Table 3. The se-

Table 2. Serum tumour marker and bone profile levels in patients with breast cancer (value are mean \pm SD)

\begin{tabular}{|c|c|c|c|c|c|c|}
\hline Group & PTH pg/ml & $\begin{array}{l}\text { Calcium } \\
\text { mg/dl }\end{array}$ & $\begin{array}{l}\text { Vitamin D } \\
\mathrm{ng} / \mathrm{ml}\end{array}$ & ALP U/L & CA-153 U/ml & CEA U/ml \\
\hline Normal control $(n=58)$ & $37.62 \pm 12.1$ & $8.505 \pm 0.57$ & $45.39 \pm 9.4$ & $76.5 \pm 21.3$ & $76.5 \pm 21.3$ & $1.035 \pm 02$ \\
\hline \multicolumn{7}{|c|}{ Breast cancer without metastasis $(n=22)$} \\
\hline Pre-menopausal level $(n=12)$ & $52.08 \pm 17^{*}$ & $9.4 \pm 0.5^{\#}$ & $47.8 \pm 4.8^{\mathrm{ns}}$ & $78.2 \pm 18.8$ & $64.9 \pm 12.3^{*}$ & $37.7 \pm 4.4^{\$}$ \\
\hline Post-menopausal level $(n=10)$ & $83.6 \pm 8.1^{\#}$ & $11.5 \pm 1.03^{*}$ & $53.05 \pm 5.6^{*}$ & $103.25 \pm 28^{*}$ & $99.2 \pm 9.4^{\#}$ & $60.7 \pm 9.7^{5}$ \\
\hline \multicolumn{7}{|c|}{ Breast cancer with metastasis $(n=36)$} \\
\hline Pre-menopausal level $(n=9)$ & $62.1 \pm 20.4^{\#}$ & $12.2 \pm 1.2^{\#}$ & $47.9 \pm 3.8^{\text {ns }}$ & $83.75 \pm 28^{\#}$ & $158.7 \pm 8.4^{\$}$ & $80.4 \pm 12^{\$}$ \\
\hline Post-menopausal level $(n=26)$ & $58.22 \pm 8.3^{\#}$ & $13.02 \pm 1.2^{5}$ & $46.55 \pm 3.7^{\mathrm{ns}}$ & $119.3 \pm 36.2^{\$}$ & $156.4 \pm 16.8^{\$}$ & $79.1 \pm 6.1^{\$}$ \\
\hline
\end{tabular}

${ }^{*} p<0.05$ and $" p<0.01,{ }^{5} p<0.001$ and ${ }^{n s}=$ non-significant 
rum levels of PTH, total calcium and tumour markers CA 153, CEA showed a significant difference between the pre and post-menopausal women within the non-metastatic group; however $25-\mathrm{OH}$ vitamin $\mathrm{D}$ and ALP did not show any significant difference between both the groups. The serum levels of total calcium, ALP did show a significant difference between the pre and post-menopausal women within the metastasis group; however, PTH and tumour markers CA 15-3, CEA and $25-\mathrm{OH}$ vitamin $\mathrm{D}$ did not show any significant difference between both the groups.

\section{Correlations of serum tumour markers with the bone profile in patients with breast cancer}

Correlations of serum tumour markers with biochemical markers of bone in patients with breast cancer were made. The differences of the results in the groups were (i) age significantly correlated with both breast cancer markers ( $r=0.1494$, $\mathrm{p}=0.0030$ ) (ii), whereas ALP, TSH, Mg and phosphorous did not significantly correlate with any markers in the breast cancer group, (iii) whereas calcium level was significantly correlated with both breast cancer markers $(p<0.001)$ (Table 3$)$.

Table 3. Correlation analysis between the tumour markers with biochemical marker of bone in the breast cancer group

\begin{tabular}{llllll}
\hline \multirow{2}{*}{ Bone mineral profile } & \multicolumn{2}{c}{ CA 15-3 } & & \multicolumn{2}{c}{ CEA } \\
\cline { 2 - 3 } \cline { 5 - 6 } & R square & p & & R square & p \\
\hline Age & 0.149 & $0.003^{\#}$ & & 0.166 & $0.0016^{\#}$ \\
Calcium mg/dl & 0.13 & $0.005^{\#}$ & & 0.429 & $0.001^{\text {s }}$ \\
Vitamin D (ng/ml) & 0.08 & 0.0314 & & 0.07 & $0.034^{*}$ \\
ALP (U/L) & 0.08 & 0.0320 & & 0.05 & 0.0799 \\
Albumin (mg/dl) & 0.007 & 0.5 & & 0.08 & 0.03 \\
Phosphorus mg/dl & 0.004 & 0.6 & & 0.026 & 0.2 \\
Magnesium (mg/dl) & 0.008 & 0.8 & & 0.003 & 0.6 \\
TSH (IU/ml) & 0.02 & 0.2 & & 0.017 & 0.3 \\
PTH (pg/mL) & 0.13 & 0.004 & 0.07 & $0.04^{*}$ \\
\hline
\end{tabular}

${ }^{*} \mathrm{p}<0.05$ and ${ }^{*} \mathrm{p}<0.01,{ }^{\mathrm{s}} \mathrm{p}<0.001$
Bone profile and tumour marker comparison between metastasis and non-metastasis breast cancer patients

As shown in Table 4, ALP and PTH showed a significant rise in metastatic cases as compared to non-metastatic group $(p<0.01)$, whereas there is no significant difference in the level of vitamin D ( $p>0.13)$, albumin ( $p>0.5)$, phosphorous $(p>0.3)$, $\mathrm{Mg}(\mathrm{p}>0.4)$. However, there was a significant difference in the level of serum calcium between the two groups $(p<0.001)$.

\section{Relationship between ctsk expression and clinicopathological factors in breast carcinomas}

In this study, 12 (33\%) of 36 cases were negative (-) for CTSK, 11 $(30.5 \%)$ were mildly positive, $9(25 \%)$ were moderately positive $(2+)$ and $4(11.1 \%)$ were strongly positive $(3+)$ for CTSK expression in malignant cells (Fig. 1). No relationship was demonstrated between CTSK expression and patient age, tumour size (major axis) and estrogen receptor status (Table 5). However, a significant positive relationship was found between CTSK expression and histological grade $(p<0.001)$, CTSK expression and presence or absence of distant metastasis $(p<0.05)$.

\begin{tabular}{|c|c|c|c|}
\hline Parameters & $\begin{array}{l}\text { Non-Metastasis } \\
\text { group }(n=22) \\
\text { Mean } \pm \text { SD }\end{array}$ & $\begin{array}{l}\text { Metastasis } \\
\text { group }(n=36) \\
\text { Mean } \pm \text { SD }\end{array}$ & $\mathbf{p}$ \\
\hline CA 15-3 (U/ml) & $85.2 \pm 22.3$ & $139.9 \pm 34.7$ & $\mathrm{p}<0.01$ \\
\hline $\mathrm{CEA}(\mathrm{U} / \mathrm{ml})$ & $48.05 \pm 9.07$ & $76 \pm 15$ & $\mathrm{p}<0.05$ \\
\hline Calcium (mg/dl) & $9.4 \pm 0.6$ & $13.14 \pm 1.1$ & $p<0.001$ \\
\hline Vitamin D (ng/ml) & $25.3 \pm 11.3$ & $26.8 \pm 10.8$ & $p>0.13$ \\
\hline $\operatorname{ALP}(\mathrm{U} / \mathrm{L})$ & $110.1 \pm 54.2$ & $82.9 \pm 51.3$ & $\mathrm{p}<0.05$ \\
\hline Albumin (g/dl) & $3.9 \pm 2.3$ & $4.0 \pm 1.3$ & $\mathrm{p}>0.5$ \\
\hline Phosphorous (mg/dl) & $3.8 \pm 0.8$ & $3.5 \pm 0.5$ & $p>0.3$ \\
\hline Magnesium (mg/dl) & $1.8 \pm 0.29$ & $1.9 \pm 0.2$ & $p>0.4$ \\
\hline $\mathrm{TSH}(\mathrm{IU} / \mathrm{ml})$ & $2.8 \pm 1.6$ & $2.4 \pm 1.9$ & $p>0.31$ \\
\hline PTH (pg/mL) & $56.3 \pm 18.7$ & $68.4 \pm 19.1$ & $\mathrm{p}<0.05$ \\
\hline
\end{tabular}

TSH: Thyroid stimulating hormone, PTH: Parathyroid hormone

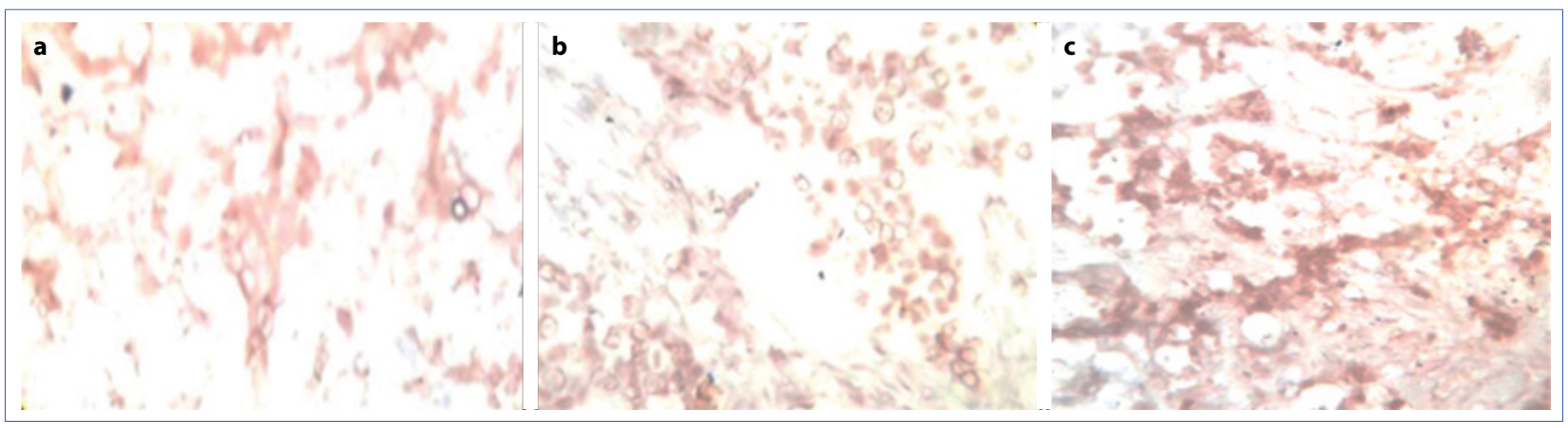

Figure 1. (a-c) Depicted is the representative immunostaining pattern of CTSK (a) mildly positive stain benign breast tissues, (b) moderately positive stain grade II breast cancer tissues, (c) strongly positive stain grade III breast cancer tissues (Magnification 40x). 
Table 5. Relationship between CTSK expression and clinicopathological factors in breast carcinomas by Chi-square test

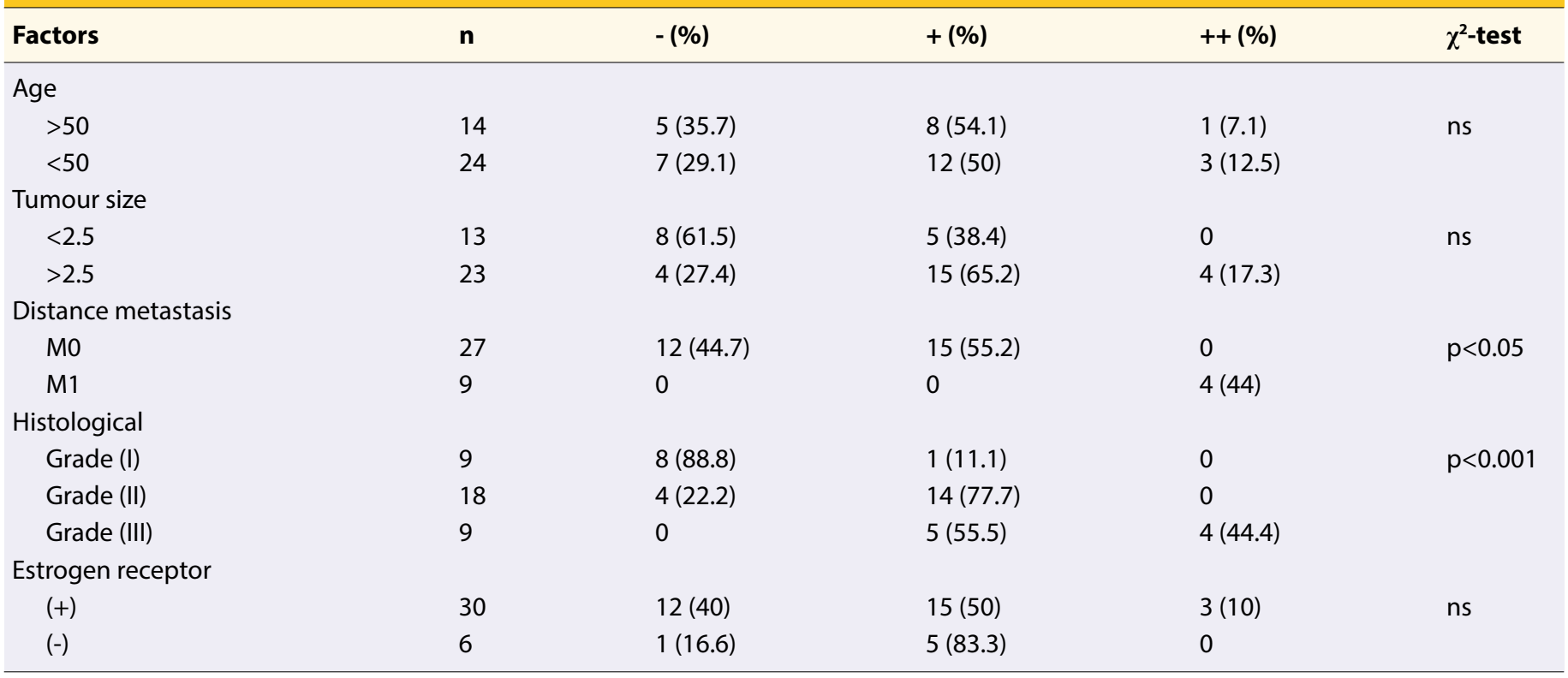

\section{Discussion}

The present study has shown that women with breast cancer have higher levels of total serum calcium and higher levels of ALP and PTH than control subjects. Other malignancies also reported hypercalcemia and high ALP and PTH activity [1416]. Hypercalcemia has been linked to osteolytic bone metastases, responsible for $20-30 \%$ of breast cancer metastasis. According to the previous studies, increased skeletal invasion and tumour destruction triggered by tumour development of various cytokines, such as growth factors (TGF- $\beta$ ), tumour necrosis factor- $\alpha$ (TNF- $\alpha$ ), interleukin-1 and interleukin- 2 leads to increasing bone osteolysis and modification of the reabsorption, excretion and resorption of calcium and phosphate ion, causes a high level of calcium [17].

ALP has many isoenzymes located in the liver, bones, and smaller amounts in intestines, placenta, kidneys, and leucocytes [18]. Another ALP isoenzyme called Regan isoenzyme has also been identified in various malignancies [19], which may contribute to increased ALP activity in breast cancer patients. This enzyme elevated activity seen in study participants can also be linked to osteolytic bone metastases in breast cancer, leading to increased osteoclastic activity and bone resorption. However, the rise in serum ALP levels is non-specific, as it is also frequently associated with many other diseases. Also, the elevation of ALP activity to less than three times the normal level is usually not considered significant [14]. In the present study, ALP and calcium showed a non-significant rise in non-metastatic cases and registered a significant rise $(p<0.001)$ in metastatic patients, respectively, which is consistent with the findings of Uemura et al. [20] and Mulholland et al. [21] which indicate no significant difference in ALP levels in non-metastatic breast cancer. Atoe et al. [22] revealed a significant rise in ALP and calcium in metastasis and no change in non-metastatic groups, which suggested the involvement of bone in cancer metastasis.

Multiple epidemiological studies have shown the link between C-reactive protein (CRP) and the risk of breast cancer [23]. Nonetheless, the findings of multiple studies testing the interaction of CRP with breast cancer in different ethnic groups have shown inconsistencies [24]. Some studies showed an association between elevated CRP and poor prognosis, while other studies found no association [25]. Guo et al. [26] conducted the largest study, which involved 5.286 patients with breast cancer. This meta-analysis found that elevated levels of CRP are correlated with increased risk of breast cancer [26]. Another study reported a high level of CRP at the time of breast cancer diagnosis which was associated with decreased overall survival and disease-free survival and increased breast cancer death [23]. In the present study, we found that CRP levels in patients with breast cancer significantly elevated at the time of diagnosis $(p<0.001)$ compared with healthy controls.

Carcinogenesis causes magnesium mobilization through blood cells and magnesium depletion in non-neoplastic tissue. At the same time, Mg deficiency seems to be carcinogenic. It has been found that supplementation of a high level of magnesium inhibits carcinogenesis in case of solid tumours [27]. Serum magnesium lower than $1.8 \mathrm{mg} / \mathrm{dL}$ is considered low. In the present study, magnesium was deficient in $42 \%$ of the patients with breast cancer and in $5 \%$ of the control group. Magnesium levels were significantly lower in the breast cancer group ( $p<0.001)$, which is in agreement with Sartori et al. [23] and Atoe et al. [22], which suggests that serum Mg was significantly lower in the patients with breast cancer compared to the control group and contradictory to the findings by Arinola et al. [28] who reported 
slight hypomagnesaemia in patients with breast cancer. Abdelgawad et al. [29] found no significant difference when comparing $\mathrm{Mg}$ levels between the breast cancer and the control group. According to previous study, magnesium deficiency has been found to be involved in both cancer risk and prognosis, including breast cancer [26, 30-32]. Several studies also indicate the impact of dietary magnesium on breast cancer prognosis $[24,33]$. Their results suggest that a higher dietary intake of magnesium among patients with breast cancer is inversely linked to mortality [34]. To date, the link between dietary magnesium consumption and the risk of breast cancer has been investigated by few epidemiological trials. A case-control study from Italy found that the serum magnesium level among patients with breast cancer was significantly lower than among control subjects [26], in line with our result.

25-OH Vitamin D status is known to be inversely related to serum PTH. The higher level of PTH in patients with breast cancer in the present study does not appear to be as a result of lower circulating $25-\mathrm{OH}$ Vitamin $\mathrm{D}$ because there was no difference in serum $25-\mathrm{OH}$ Vitamin $\mathrm{D}$ between patients with breast cancer and control subjects. The mean serum $25-\mathrm{OH}$ Vitamin $D$ in both groups was below $28.3 \mathrm{ng} / \mathrm{mL}$, which is consistent with previous reports suggesting that $25-\mathrm{OH}$ Vitamin D deficiency or insufficiency is prevalent across the globe in almost all age groups and geographic areas [35].

The total cholesterol observed among the patients with breast cancer in the present investigation was within the normal range, but there is a significant change in the level of HDL and VLDL and no change in LDL level. This finding is consistent with the studies of Ramaswamy et al. [36] and Damodar et al. [37] which reported a non-significant change in total serum cholesterol of breast cancer cases. However, this is in contrast to the studies of Qi and Owiredu et al. [38], which reported that elevated total serum cholesterol with increased breast cancer risk.

Several studies have consistently reported the prognostic value of serum albumin in patients with breast cancer. Low levels of albumin have been associated with increased cancer risk, and elevated levels of albumin $(>3.5 \mathrm{~g} / \mathrm{dl})$ are significantly associated with improved overall survival among patients with breast cancer [39]. The present results are consistent with previous findings of Boonpipattanapong et al. [40], Win et al. [41] and Neal et al. [42]. The result provides strong evidence that lower serum albumin level is a prognostic factor for poor survival in early-stage patients with breast cancer regardless of stages. We observed an independent association between low baseline levels of serum albumin and survival. It is likely that serum albumin is a marker for patients with severe disease. Interestingly, our analysis suggests that low levels of serum albumin identify patients with the most severe disease within each tumour stage.

In the present study, serum TSH and phosphorus level in breast carcinoma women were within a normal range. This finding is in agreement with the report of non-significant change in total serum level of TSH and phosphorous [43]. Elevated levels of serum TSH and phosphorus are associated with advanced breast cancer [44].

The predominant expression of CTSK resulted in acute increase in serum calcium level and CTSK inhibition by SI-591 decreased serum calcium level in a rodent in-vivo study [45]. The current study reported that positive CTSK staining was detected in $55 \%$ of the breast tumours. There have been many studies concerning CTSK expression in breast carcinoma by immunohistochemistry [46, 7].

Evaluating the association of elevated CTSK with various histological grade $(p<0.001)$, presence or absence of distant metastasis $(p<0.05)$, we found that elevated CTSK levels associated significantly with histological grade I, II and III. This is in contradiction with the recent study that reported a significant association of negative ER status with elevated CTSK levels [46]. However, this study was carried out involving only 58 patients with breast cancer and, therefore, needs to be confirmed involving a larger cohort of patients. In addition, there was no significant difference in CTSK levels among premenopausal and postmenopausal patients with breast cancer $(p<0.5)$. Higher and moderate CTSK levels were associated with a significantly presence or absence of distant metastasis $(p<0.05)$. Therefore, moderate and high CTSK levels were possibly associated with significantly with poor outcomes, including death, recurrence and metastasis. To our knowledge, there is no published literature on CTSK in association with histological grade and distance metastasis and this will be the first study. The levels of CTSK were assessed at the time of disease diagnosis and the outcome measures were robust. However, limitations of this study are that we could not collect detailed data on receptor measurements, organ specific metastasis and lymph node status.

\section{Conclusion}

The estimation of serum bone profiles has a potential role in the early detection and monitoring of patients with breast cancer. The present study suggests that CTSK expression is not only correlated with metastasis but also related to the progression of breast carcinoma, and its overexpression could be potential prognostic factor for human breast carcinoma. The present study indicates CTSK as a potential molecule for diagnosis and therapeutic target for the treatment of breast cancer metastasis. However, none of the previous studies, as well as this study, determine whether this association has diagnostic value. If CTSK plays a critical role in breast cancer outcomes, then the future researchers need to focus on understanding how interventions can reduce the concentration of this bone resorption marker. In accordance with our study, if CTSK is a novel prognostic marker, then future studies are required to understand if it is responsive to drug and lifestyle interventions need to be designed to reduce the risk of skeletal metastasis in breast cancer women. 
Acknowledgements: We would like to thank all of the study participants as well as the staff of the hospital. The authors are also thankful to the University Grant Commission UGC: NFST India for funding to carry out this work.

Conflict of Interest: The authors do not have any conflict of interest in the manuscript.

Ethics Committee Approval: This study was approved by the ethics board of Saveetha Medical College \& Hospital Chennai and Gleneagles Global Health City Hospital Chennai, India. (Date: 11.04.2015)

Financial Disclosure: This work was financially supported by the University Grant Commission (UGC) for UGC: NFST India with IF no. NFST-2015-17-ST- MAN-689.

Peer-review: Externally peer-reviewed.

Authorship Contributions: Concept - Y.V.; Design - Y.V.; Supervision - S.S.; Funding - U.G.C.; Materials - Y.V., T.K., M.S.; Data collection \&/or processing - T.K., M.S.; Analysis and/or interpretation - Y.V., F.B.S.; Literature search - Y.V.; Writing - Y.V., F.B.S.; Critical review - S.S.

\section{References}

1. Agarwal G, Pradeep PV, Aggarwal V, Yip CH, Cheung PS. Spectrum of breast cancer in Asian women. World J Surg 2007;31(5):1031-40. [CrossRef]

2. Rangarajan B, Shet T, Wadasadawala T, Nair NS, Sairam RM, Hingmire SS, et al. Breast cancer: An overview of published Indian data. South Asian J Cancer 2016;5(3):86-92. [CrossRef]

3. Doddala SM, Suryadevara A, Chinta SK, Madisetty AL. Incidence and pattern of bone metastases at presentation in Indian carcinoma breast patients. Indian J Cancer 2016;53(3):360-2.

4. Kang Y, Massagué J. Epithelial-mesenchymal transitions: twist in development and metastasis. Cell 2004;118(3):277-9. [CrossRef]

5. Pedica F, Pecori S, Vergine M, Brunelli M, Montagna L, Pedron $S$, et al. Cathepsin-k as a diagnostic marker in the identification of micro-granulomas in Crohn's disease. Pathologica 2009;101(3):109-11.

6. Le Gall C, Bonnelye E, Clézardin P. Cathepsin K inhibitors as treatment of bone metastasis. Curr Opin Support Palliat Care 2008;2(3):218-22. [CrossRef]

7. Zheng G, Martignoni G, Antonescu C, Montgomery E, Eberhart C, Netto G, et al. A broad survey of cathepsin K immunoreactivity in human neoplasms. Am J Clin Pathol 2013;139(2):151-9.

8. Duong LT, Wesolowski GA, Leung P, Oballa R, Pickarski M. Efficacy of a cathepsin $\mathrm{K}$ inhibitor in a preclinical model for prevention and treatment of breast cancer bone metastasis. Mol Cancer Ther 2014;13(12):2898-909. [CrossRef]

9. Brubaker KD, Vessella RL, True LD, Thomas R, Corey E. Cathepsin $\mathrm{K}$ mRNA and protein expression in prostate cancer progression. J Bone Miner Res 2003;18(2):222-30. [CrossRef]

10. Bitu CC, Kauppila JH, Bufalino A, Nurmenniemi S, Teppo S, Keinänen $M$, et al. Cathepsin $K$ is present in invasive oral tongue squamous cell carcinoma in vivo and in vitro. PLoS One 2013;8(8):e70925. [CrossRef]

11. Herroon MK, Rajagurubandara E, Rudy DL, Chalasani A, Hardaway AL, Podgorski I. Macrophage cathepsin K promotes prostate tumor progression in bone. Oncogene 2013;32(12):1580-93. [CrossRef]

12. Yamashita $\mathrm{K}$, Iwatake $M$, Okamoto $\mathrm{K}$, Yamada SI, Umeda $M$, Tsukuba T. Cathepsin $\mathrm{K}$ modulates invasion, migration and adhesion of oral squamous cell carcinomas in vitro. Oral Dis 2017;23(4):518-25. [CrossRef]

13. Hlaing TT, Compston JE. Biochemical markers of bone turnover - uses and limitations. Ann Clin Biochem 2014;51(Pt 2):189-202.

14. Wiwanitkit V. High serum alkaline phosphatase levels, a study in 181 Thai adult hospitalized patients. BMC Fam Pract 2001;2:2. [CrossRef]

15. Heys SD, Smith IC, Eremin O. Hypercalcaemia in patients with cancer: aetiology and treatment. Eur J Surg Oncol 1998;24(2):139-42. [CrossRef]

16. Ijaz A, Mehmood T, Qureshi AH, Anwar M, Dilawar M, Hussain I, Khan FA, Khan DA, Hussain S, Khan IA. Estimation of ionized calcium, total calcium and albumin corrected calcium for the diagnosis of hypercalcemia of malignancy. J Coll Physicians Surg Pak. 2006;16(1):49-52.

17. Francini G, Petrioli R, Maioli E, Gonnelli S, Marsili S, Aquino A, Bruni S. Hypercalcemia in breast cancer. Clin Exp Metastasis. 1993;11(5):359-367. [CrossRef]

18. Friedman LS, Martin P, Munoz SJ. Liver Function tests and the objective evaluation of the patient with liver disease. In: Zakim D, Boyer T D, editors. Hepatology: a Textbook of liver diseases. Philadelphia: WB Saunders; 1996. p. 791-833.

19. Fishman WH, Inglis NI, Stolbach LL, Krant MJ. A serum alkaline phosphatase isoenzyme of human neoplastic cell origin. Cancer Res 1968;28(1):150-4

20. Uemura H, Irahara M, Yoneda N, Yasui T, Genjida K, Miyamoto $\mathrm{Kl}$, et al. Close correlation between estrogen treatment and renal phosphate reabsorption capacity. J Clin Endocrinol Metab 2000;85(3):1215-9. [CrossRef]

21. Mulholland HG, Murray LJ, Anderson LA, Cantwell MM; FINBAR study group. Vitamin D, calcium and dairy intake, and risk of oesophageal adenocarcinoma and its precursor conditions. Br J Nutr 2011;106(5):732-41. [CrossRef]

22. Atoe KJ, Idemudia O, Eboreime O. Serum Magnesium Levels in Women with Breast Cancer in Benin City, Nigeria. Int J Tropical Disease Health 2014;4(6):723-8 [CrossRef]

23. Sartori S, Nielsen I, Tassinari D, Mazzotta D, Vecchiatti G, Sero $A$, et al. Serum and erythrocyte magnesium concentrations in solid tumours: relationship with stage of malignancy. Magnes Res 1992;5(3):189-92.

24. Favaro E, Amadori A, Indraccolo S. Cellular interactions in the vascular niche: implications in the regulation of tumor dormancy. APMIS 2008;116(7-8):648-59. [CrossRef]

25. Pasanisi P, Venturelli E, Morelli D, Fontana L, Secreto G, Berrino F. Serum insulin-like growth factor-I and platelet-derived growth factor as biomarkers of breast cancer prognosis. Cancer Epidemiol Biomarkers Prev 2008;17(7):1719-22. [CrossRef] 
26. Guo L, Liu S, Zhang S, Chen Q, Zhang M, Quan P, et al. C-reactive protein and risk of breast cancer: A systematic review and meta-analysis. Sci Rep 2015;5:10508. [CrossRef]

27. Durlach J, Bara M, Guiet-Bara A, Collery P. Relationship between magnesium, cancer and carcinogenic or anticancer metals. Anticancer Res 1986;6(6):1353-61.

28. Arinola OG, Charles-Davies MA. Micronutrient levels in the plasma of Nigerian females with breast cancer. Afri J Biotech 2008;7(11):1620-1623. [CrossRef]

29. Abdelgawad IA, El-Mously RH, Saber MM, Mansour OA, Shouman SA. Significance of serum levels of vitamin D and some related minerals in breast cancer patients. Int J Clin Exp Pathol 2015;8(4):4074-82.

30. Blaszczyk U, Duda-Chodak A. Magnesium: its role in nutrition and carcinogenesis. Rocz Panstw Zakl Hig 2013;64(3):165-71.

31. Castiglioni S, Maier JA. Magnesium and cancer: a dangerous liason. Magnes Res 2011;24(3):S92-100. [CrossRef]

32. Wolf FI, Maier JA, Nasulewicz A, Feillet-Coudray C, Simonacci M, Mazur A, et al. Magnesium and neoplasia: from carcinogenesis to tumor growth and progression or treatment. Arch Biochem Biophys 2007;458(1):24-32. [CrossRef]

33. Tao MH, Dai Q, Millen AE, Nie J, Edge SB, Trevisan M, et al. Associations of intakes of magnesium and calcium and survival among women with breast cancer: results from Western New York Exposures and Breast Cancer (WEB) Study. Am J Cancer Res 2015;6(1):105-13. [CrossRef]

34. Yang CY, Chiu HF, Cheng MF, Hsu TY, Cheng MF, Wu TN. Calcium and magnesium in drinking water and the risk of death from breast cancer. J Toxicol Environ Health $A$ 2000;60(4):231-41. [CrossRef]

35. Edwards $M H$, Parsons $C$, Bruyère $O$, Petit Dop $F$, Chapurlat $\mathrm{R}$, Roemer FW, et al; SEKOIA Study Group. High KellgrenLawrence Grade and Bone Marrow Lesions Predict Worsening Rates of Radiographic Joint Space Narrowing; The SEKOIA Study. J Rheumatol 2016;43(3):657-65. [CrossRef]
36. Ramaswamy G, Rao VR, Krishnamoorthy L, Ramesh G, Gomathy $R$, Renukadevi $D$. Serum levels of bone alkaline phosphatase in breast and prostate cancers with bone metastasis. Indian J Clin Biochem 2000;15(2):110-3. [CrossRef]

37. Damodar G, Smitha T, Gopinath S, Vijayakumar S, Rao Y. An evaluation of hepatotoxicity in breast cancer patients receiving injection Doxorubicin. Ann Med Health Sci Res 2014;4(1):74-9.

38. Owiredu WK, Donkor S, Addai BW, Amidu N. Serum lipid profile of breast cancer patients. Pak J Biol Sci 2009;12(4):332-8.

39. Kaur RP, Rubal, Dhiman M, Vashitstha R, Munshi A. Serum Albumin Levels in Breast Cancer: Correlation with Overall Survival. J Food Nutr Disord 2017;6(5).

40. Boonpipattanapong T, Chewatanakornkul S. Preoperative carcinoembryonic antigen and albumin in predicting survival in patients with colon and rectal carcinomas. J Clin Gastroenterol 2006;40(7):592-5. [CrossRef]

41. Win T, Sharples L, Groves AM, Ritchie AJ, Wells FC, Laroche CM. Predicting survival in potentially curable lung cancer patients. Lung 2008;186(2):97-102. [CrossRef]

42. Neal CP, Mann CD, Sutton CD, Garcea G, Ong SL, Steward WP, et al. Evaluation of the prognostic value of systemic inflammation and socioeconomic deprivation in patients with resectable colorectal liver metastases. Eur J Cancer 2009;45(1):56-64. [CrossRef]

43. Al Dleemy WKA. Effect of Some Antioxidant Parameters in Breast Cancer. Tikrit Journal of Pure Science 2009;14(2):46-50.

44. Pavithra V, Sathisha TG, Kasturi K, Mallika DS, Amos SJ, Ragunatha $S$. Serum levels of metal ions in female patients with breast cancer. J Clin Diagn Res 2015;9(1):25-7. [CrossRef]

45. Fujii T, Ishikawa M, Kubo A, Tanaka Y. Effect of SI-591, a new class of cathepsin $\mathrm{K}$ inhibitor with peptidomimetic structure, on bone metabolism in vitro and in vivo. Bone 2015;81:427-34.

46. Kleer CG, Bloushtain-Qimron N, Chen YH, Carrasco D, Hu M, Yao J, et al. Epithelial and stromal cathepsin K and CXCL14 expression in breast tumor progression. Clin Cancer Res 2008;14(17):5357-67. [CrossRef] 